
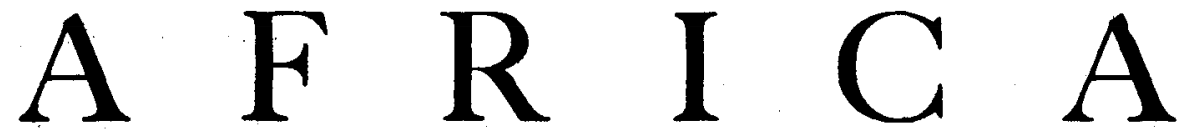

JOURNAL OF THE INTERNATIONAL INSTITUTE OF AFRICAN LANGUAGES AND C ULTURES

\title{
TO THE MEMBERS OF THE INSTITUTE
}

TN the last complete issue of Africa (July 1940) I was compelled to inform members 1 that the hopes which I had expressed in the Circular of October 1939 that we should be able to continue its publication and our other work in spite of the war, did not seem to be possible of realization. The British members of the Bureau had therefore decided that the Institute should suspend its activities ' for the duration'. This decision was in part due to the fact that we could no longer communicate with the Editor, Professor Westermann, and the Assistant Editor, Miss Brackett, was incapacitated by ill health. She later retired on pension, and the Administrative Director, Professor Coupland, was called upon to undertake other pressing work for His Majesty's Government.

Owing, however, to the dauntless enthusiasm of the Secretary-General, Sir Hanns Vischer, who consented to undertake Professor Coupland's duties as Administrative Director, notwithstanding his absorption in war work, the Institute has, as you are aware, been able to keep its office open and to publish a quarterly bulletin by arrangement with the Royal African Society. It has thus remained in touch with nearly 800 members.

Dr. Nadel's book, A Black Byzantium: The Kingdom of Nupe in Nigeria, has been published, and The Realn of a Rain-Queen: A Study of the Pattern of Lovedu Society, by Dr. and Mrs. Krige, is in the Press. I understand that Dr: Fortes's manuscript on the results of his field work is also completed.

It is entirely due to Sir Hanns's efforts and to the invaluable and generous assistance of a number of specially. qualified London members, with whose names you are alteady familiar in the bulletins, that an Interim Committee was formed, a SubCommittee of which has undertaken the editorship of Africa. They desire me to say that they are fully aware of their inability in present circumstances to maintain the high pre-war standard of the Journal, but they rely on the support and interest of members.

The Interim Committee has now, by the inclusion of nationals of the various Governments residing in London, been able to resume as far as circumstances permit the international status of the Institute. It has recently formed a closer liaison with

'Africa', the Journal of the International Institute of African Languages and Cultures, is published by the Institute, but except where otherwise stated the writers of the articles are alone responsible for the opinions expressed. 
the London School of Oriental and African Studies, several members of which have joined the Committee.

I take this opportunity of expressing the pleasure which I know will be felt by all members that His Majesty the King has recently recognized his public services by conferring a knighthood upon Sir Hanns Vischer.

Miss Brackett's retirement due to ill health is an irreparable loss to the Institute, to which she has devoted her undivided energies and great ability for fifteen years since its foundation. She will indeed be greatly missed by those who have had the pleasure of working with her.

November 1942

LUGARD

Chairman of Executive Council

Step by step our Institute resumes its functions as an international centre and clearing-house for information regarding study and research in the field of African languages and cultures.

In view of the many inquiries we have received, we feel that members will be pleased to see the reappearance of our Journal Africa, and to learn from the Chairman's note how this has been made possible. Our Editorial Committee consists of Dr. Ida Ward and Miss M. Green of the School of Oriental and African Studies, Dr. Margaret Read, Director of the Colonial Department of the London University Institute of Education, and Miss M. Wrong, Secretary of the International Committee on Christian Literature for Africa. Miss R. Jones is acting as assistant editor. The Committee will be glad to receive articles and information of interest to our members for publication in future numbers.

Another development of our work began with the first of a series of International Discussion Meetings planned by the Institute in conjunction with the School of Oriental and African Studies. An account of the first meeting, at which General Sicé of the Fighting French Forces spoke, will be found in this issue. The attendance of many well-known people, and the keenness of the discussion which followed General Sicé's paper showed that the meetings respond to a definite demand. Future speakers will include Belgian and Dutch officials. The meetings have been arranged with a view to providing an opportunity for studying the way in which problems common to all colonial territories are approached by the various Governments. One of these problems is the illiteracy of the great mass of African people, and we hope to hear in the course of further meetings how this problem has been tackled in China, Russia, and Turkey.

A review of Dr. Nadel's book, mentioned in the Chairman's note, will appear in our April number. From expert opinion already expressed we understand that the book represents a brilliant piece of field research. Members ordering the book from this Institute will be entitled to the usual discount of $12 \frac{1}{2}$ per cent. on the published price of $25 s$.

In response to the announcement regarding our Prize Essay Competition in our bulletin of January 1942, essays are beginning to arrive from various parts of Africa. May we remind competitors that their manuscripts should be sent off not later than I April r943. 
Members will note with satisfaction from the Audited Accounts and Balance Sheet circulated with this issue that the financial position of the Institute is sound, and they will endorse the vote of thanks passed by the Interim Committee to our Hon. Treasurer, Sir Humphrey Leggett, our Hon. Auditors, Messrs. Mann, Judd, Gordon \& Co., and to Mr. Leith of that firm for his constant supervision of our accounts.

HANNS VISCHER

Secretary-General and Acting Administrative Director

\section{THE LATE PROFESSOR EUGEN MITTWOCH}

Members of the Institute and students of Arabic and African Languages all over the world will have heard with deep regret of the death of this great scholar who passed away on November 8 th in London, where he had lived since 1935 . He began his studies in Berlin where he took his degree of Dr. Phil. in 1899 . After visiting Egypt, Palestine and Syria he became Privat-Dozent in Berlin in 1909 and Professor in I915. In 1920 he was appointed Director of the Seminar für Orientalische Sprachen and held that post until 1933 . Two years later, having been dismissed for being a Jew, he came to England and continued his studies quietly in London. He represented the Deutsche Morgenländische Gesellschaft on the Governing Body of the Institute until he left Germany, and during the last few months of his life he served as a member on our Interim Committee, besides giving us most valuable advice on the production of an Amharic Grammar. He contributed many articles to the Encyclopaedia of Islam, the Journal of the Seminar für Orientalische Sprachen and other scientific periodicals. $\mathrm{He}$ was the author and co-author of many 'standard works on Arabic literature and Amharic. Of the latter, the Amharic version of the Soirées de Carthage was perhaps the most important. He was deeply religious, a great friend, and above all a great scholar, and we of the London Office of our Institute shall always consider ourselves fortunate in having been allowed to work with this kind and modest man and great savant. 